Article

\title{
When Collaborative Water Governance Meets Authoritarian Environmentalism: The Dilemma of Safe Water Supply Project in Coal Mining Villages of China's Shanxi Province
}

\author{
Jian Yan ${ }^{1}$, Rongrong $\mathrm{Li}^{2}$ and Ran Ran ${ }^{3, *}$ \\ 1 Independent Researcher, Beijing 100089, China; jian_yan@foxmail.com \\ 2 School of Politics and Public Management, Shanxi University, Taiyuan 030006, China; lirong@sxu.edu.cn \\ 3 School of International Studies, Renmin University of China, Beijing 100872, China \\ * Correspondence: rran@ruc.edu.cn
}

check for updates

Citation: Yan, J.; Li, R.; Ran, R. When Collaborative Water Governance

Meets Authoritarian

Environmentalism: The Dilemma of Safe Water Supply Project in Coal Mining Villages of China's Shanxi Province. Sustainability 2022, 14, 1277. https://doi.org/10.3390/su14031277

Academic Editors: Fernando António Leal Pacheco and Grigorios

L. Kyriakopoulos

Received: 10 November 2021

Accepted: 19 January 2022

Published: 24 January 2022

Publisher's Note: MDPI stays neutral with regard to jurisdictional claims in published maps and institutional affiliations.

Copyright: () 2022 by the authors. Licensee MDPI, Basel, Switzerland. This article is an open access article distributed under the terms and conditions of the Creative Commons Attribution (CC BY) license (https:// creativecommons.org/licenses/by/ $4.0 /)$.

\begin{abstract}
The framework of collaborative water governance (CWG) has been championed as a promising model for water management across the globe. China is a country confronted by serious water pollution and shortage problems. In recent years, many scholars and practitioners have turned to CWG as an effective model for water crisis management in China. However, the political nature of CWG and China's Authoritarian Environmentalism is inherently conflictual, hence, the development of CWG in China poses a theoretical puzzle, i.e., how the bottom-up CWG model can coexist with the top-down Authoritarian Environmentalism in China's water politics. To better understand this puzzle, this article explores CWG's intertwinement with environmental authoritarianism through a case study of "safe water supply project" in 11 coal-mining villages in Shanxi province of North China. Drawing on fieldwork between 2019 and 2021 in H city of Shangxi province, this research shows that the central government's pledge to provide safe water to every villager in rural China has not materialized so far. The dilemma of safe water supply in coal mining villages in $\mathrm{H}$ city shows that, on one side, the central government attempted to show its great will and commitment to providing safe water to everyone in rural China through an approach of environmental authoritarianism; while on the other side, the local governments tended to select the CWG model as a method for practical implementation as well as a blame avoidance strategy. Our study identifies five stakeholders in the villages' safe water supply projects: the Department of Water Resources of the City Government, the Township Government, Coal Mining Enterprises, village cadres and villagers. The outcome of the safe water supply project in these villages is constrained by the transparency and trust deficit among stakeholders when facing cooperation and conflict management obstacles.
\end{abstract}

Keywords: collaborative water governance; authoritarian environmentalism; safe water supply project; coal mining enterprises

\section{Introduction}

Water is not only essential to life on our planet but also plays a sanitary, social and cultural role at the heart of human societies. Water security is one of the most outstanding challenges the world faces today. In 2016, four billion people around the world faced severe water scarcity [1]. China is a country confronted by serious water shortage problems. The per capita fresh water resource available to the Chinese is only one fourth of the world average in 2020 [2]. By 2019, more than 60 million people in rural China continued to be plagued by a shortage of safe and clean water, a problem that is especially acute in some villages affected by coal mining in North China [3]. Coal mining can generate a number of negative environmental externalities like water pollution, water shortage, dust pollution and land erosion. Meanwhile, coal-burning power plants are widely blamed for exacerbating global warming [4]. This is why the UN Climate Change Conference in Glasgow called for accelerating efforts towards the phasedown of unabated coal power. 
The shortage of clean drinking water is not only a crisis of water resources per se. It is also a crisis of governance. This is why it has been identified as one of the highest global risks [5]. Water is generally perceived as a public good. As a result, the conventional wisdom of water governance holds that the state should be primarily responsible for controlling, managing and distributing water resources [6]. However, given the fact that water flows across political boundaries and the increasing reorientation of the state away from its position as a central governing authority of environmental resources, this command-control approach through hierarchical control without deeper political reflexivity has been criticized for its rather limited success in sustainably managing water resource in the long run [7].

In recent years, many scholars and practitioners have increasingly turned to collaborative water governance (CWG) as an alternative model for water crisis management, reflecting the shift of paradigms in the regulation, management and governance of natural resources [8]. The CWG approach advocates a new kind of coalition among governments and their agents on the one hand and civil society organizations on the other. Relevant actors in CWG are typically held together by guidelines, plans and non-binding agreements. Advocates of the CWG approach believe that engaging multiple actors across different levels of government and between the public and the private sectors as well as the participation and cooperation of various stakeholders are essential for opening up decision making related to water governance and bringing local knowledge back in, all of which is expected to yield a higher degree of policy legitimacy and more effective environmental governance [5]. Correspondingly, since the 1980s good governance of water resources has increasingly been linked to institutions and laws that more effectively engage local actors and are more attuned to local ecosystems [9].

The mainstream theory on water management has witnessed a transition from the conventional top-down command-control approach to a more collaborative one; however, in reality, CWG's performance is mixed at best under different social, economic and political systems [10,11]. Viewing CWG abstractly as a solution to essentially technical and managerial problems overlooks the social and therefore political processes that determine what water is, whom it is for and how it should be allocated in the quest for water security [7]. The research of Cain and his co-authors on California's Integrated Regional Water Governance Program shows one of the obstacles to the success of CWG is that cooperation is especially difficult when collaborations are externally generated by higher levels of government as opposed to self-generated by local agencies and stakeholders due to the lack of spontaneity [12].

Much research and many policy recommendations highlight the effectiveness of CWG in addressing various water crises in China $[11,13]$. However, few studies have critically examined the role of political context in shaping the dynamics, narratives and performance of CWG in China. Since 2012, China's macro-political context under which water governance plays out has experienced a sharp turn from de facto decentralization to re-centralization, exemplified by the iron-handed crackdown on pollution, centrally initiated campaign-style inspections and surveillance of the internet and online data, among other things [14]. Through the model of "Authoritarian Environmentalism", researchers attempt to illustrate not only how the Chinese government uses top-down means for the end of better environmental governance but also how state-led environmentalism often serves non-environmental ends by strengthening the power of the state [15].

As an alternative to the mainstream claim that democracies tend to yield better environmental governance performance, the Authoritarian Environmentalism model alleges that authoritarianism is more effective than democracy in addressing both domestic and global environmental crises [16]. However, whether and to what degree China's authoritarian environmentalism outperformed its democratic counterparts is an open question that has yet to be examined by empirical studies. The political nature of CWG and Authoritarian Environmentalism is inherently conflictual; hence, the development of CWG in China poses a theoretical puzzle, i.e., how the bottom-up CWG model can coexist with the 
top-down Authoritarian Environmentalism in China's water politics. To better understand this puzzle, this article explores the intertwinement between CWG and Authoritarian Environmentalism in the safe water supply project (SWSP) in 11 coal-mining villages in Shanxi province of North China (see Figure 1).

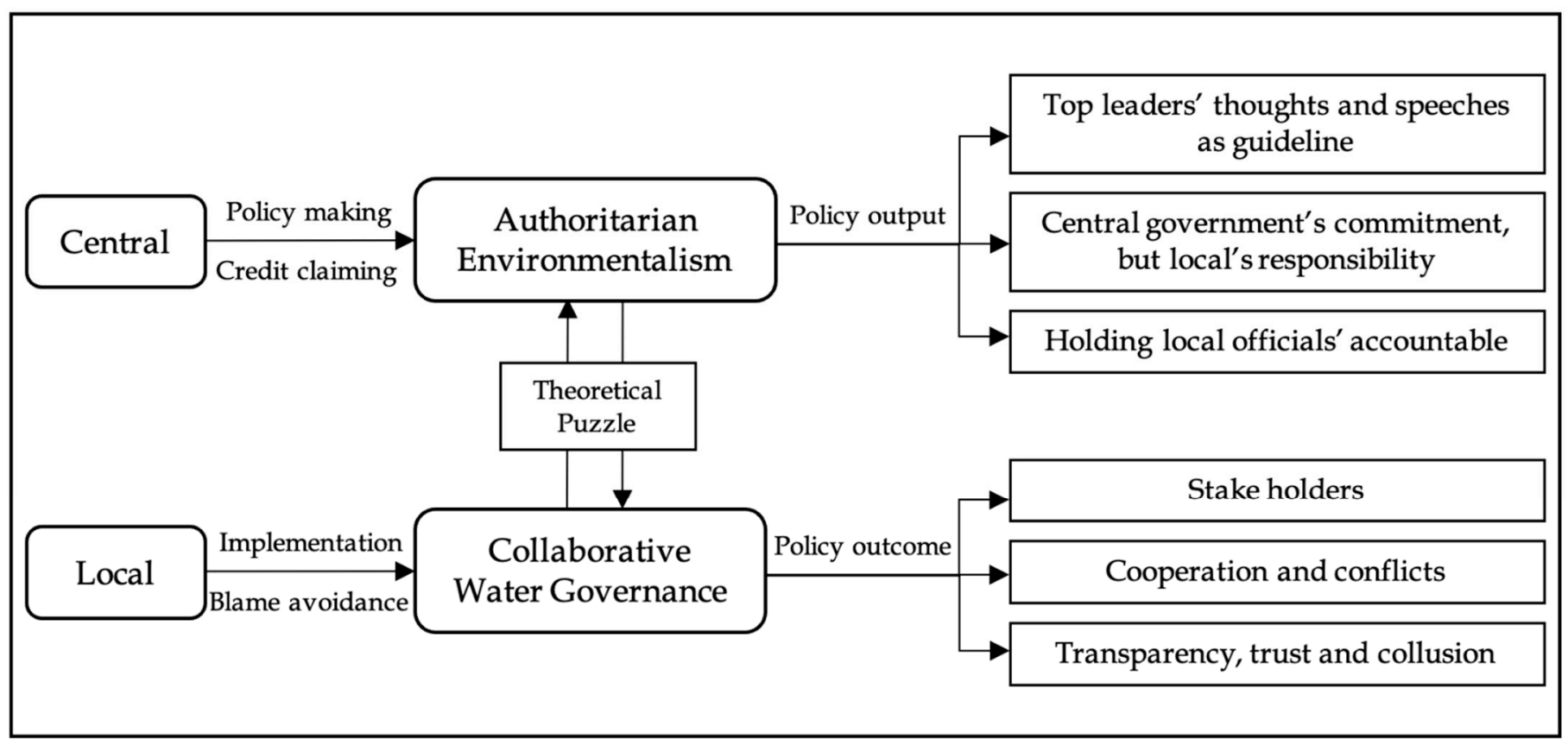

Figure 1. Analytical framework.

Drawing on extensive fieldwork conducted between 2019 and 2021, this research shows that the central government's pledge to provide safe water to every villager in rural China has not yet materialized. The dilemma of safe water supply in coal mining villages in Shanxi province showed that, on one side, the central government attempted to show its great will and commitment to providing safe water supply to everyone in rural China using an approach of environmental authoritarianism; but on the other side, the local government opted for the CWG model for practical implementation and as a strategy for blame avoidance. Our study identifies five stakeholders in villages' SWSP: the city Departments of Water Resources (DWR), the Township Governments, Coal Mining Enterprises (CME), village cadres and villagers. The outcomes of the SWSP, however, are constrained by the transparency and trust deficit among stakeholders when facing cooperation and conflict management obstacles.

This article proceeds as follows: Section 1 presents a critical review of the literature on CWG and its applications in China, followed by a summary of our fieldwork and data in Section 2. Section 3 maps out the shift from the Fragmented Authoritarianism model to Authoritarian Environmentalism Framework. Section 4 examines the congruence of China's central leadership's lofty pledges to provide safe water supply to every villager with the Authoritarian Environmentalism Model, which is followed by an analysis of local governments' preference for the CWG approach as an implementation as well as a blame avoidance strategy in Section 5. Conclusions are summarized in Section 6.

\section{Literature Review, Fieldwork and Data}

\subsection{Why Political Context Matters in CWG}

The concept of "collaborative water governance" originates from "collaborative governance," a key concept that emerged in the 1970s' shift of public administration and democratic discourse [17]. Ansell and Gash define collaborative governance broadly as "the processes and structures of public policy decision making and management that en- 
gage people constructively across the boundaries of public agencies, levels of government and/or the public, private and civic spheres in order to carry out a public purpose that could not otherwise be accomplished" [18]. Since the 1990s, in the area of environmental management, the collaborative governance approach has emerged in the western democratic systems as a response to the failures of government's command-and-control approach in managing environmental issues such as water pollution and water scarcity [19].

The CWG approach emphasizes such values as bargaining, negotiation and compromise. CWG advocates believe that collaboration is especially effective in resolving conflicts, improving relations among stakeholders, addressing multifaceted problems and correcting the deficiencies of the approaches that prefer centralized government control or technical knowledge. Indeed, the CWG approach reflects a shift from the focus either on market-based interactions or hierarchical government control, which are often rendered ineffective when it comes to resolving complex problems related to water management.

Collaborative water governance involves more than responding to neutral technical and managerial problems. Instead, it is an inherently political process that reflects a complex web of interests, narratives and power [20]. Established studies have largely concentrated on the application of CWG in the democratic governance system of the west. In theory, the assumed benefits of the CWG Model include improved participation and inclusion, better efficiency and responsiveness, peaceful management of conflicts, enhanced social and institutional capacities to address complex water management issues and more effective transfer of knowledge and best practices [7]. In reality, however, successful implementation of the CWG model rests upon the existence of trust, participation, transparency, accountability and legitimacy which are often absent in some non-democratic systems [21].

Variations of CWG across different political systems and its performance gap in nonwestern political systems have been reported in the in current literature. As Cisneros's study on Latin America shows, state regulations that were designed to homogenize stakeholders' participation in water governance could deepen structural inequalities by making it harder for some actors to collaborate [10]. A study on a mining area in South Africa shows that collusion and corruption of government representatives, traditional leaders and mining companies negatively affect the availability and quality of clean water for local communities [22].

\subsection{China's State-Led CWG Model}

In spite of its origin in western democratic contexts, in the past decade the CWG model has been hailed in many research and policy recommendations for its effectiveness in addressing water crises in China $[23,24]$. For example, a study of a pilot project on interagency cooperation in local water governance in Dongguan city of Guangdong Province shows that local agencies have come to terms with the need for cooperation in managing water resources and the imperative of establishing an integrative department on managing water resources along with extending the scope of the collaborative network [11].

The "River Chief System" (RCS), for example, is widely praised as a successful example of CWG in China for solving complex collaborative problems among administrative departments, local governments and various sectors in water governance [13]. First established in 2008, RCS entrusted Party and government leaders at all administrative levels of China to work as "River Chiefs" in their regions, responsible for the management and protection of the parts of rivers and lakes under their respective jurisdiction. River Chiefs are expected to shoulder such responsibilities as water resources protection, shoreline management, water pollution prevention and control, water environment management, water ecological restoration and water-related law enforcement [25]. It is reported that RCS has contributed to remarkable water quality improvement between 2016 and 2019 across China [26]. It is widely noted that the implementation of CWG in China is deeply rooted in China's top-down administrative system and shaped by the party-state's hierarchical logic [27]. One advantage of RCS is that it can facilitate collaboration in water 
governance since it incorporates all stakeholders into water management framework under the leadership and supervision of the party-state [13].

However, the role of the political regime in shaping the performance of China's government-led CWG model is still being debated in the literature. Some researchers insist that China's state-led CWG is effective in addressing the problems of administrative fragmentation, which is often cited as one of the gravest challenges in water governance across China [26]. In contrast, others claim that the Chinese-style CWG in essence represents a top-down approach for mobilizing relevant actors and resources. It merely strengthens the personal authority of Party and government leaders in water management but fails to create an inclusive platform for communications, trust-building, dialogue and mutual understanding among the stakeholders [25]. For example, some researchers find that the performance of RCS largely hinges either on interventions from higher authorities or on whether local leaders in China's political hierarchy put water-related issues at the top of their agendas [27]. Like other forms of "head responsibility system," RCS delegates centralized powers to the River Chiefs and ensures that they will have the discretion in using such powers as they see fit. Some researchers allege that RCS has greatly strengthened the awareness of public participation among ordinary citizens, thanks to the government's efforts to disclose vital information regarding water governance (e.g., information on water pollution) via social media. However, such a conclusion has been challenged by other researchers, who argue that public participation has been held back by the information control and non-transparency under RCS [28].

China's state-led CWG model thus poses a significant theoretical puzzle to the mainstream CWG literature, i.e., how does the bottom-up CWG model work in and adapt to the top-down authoritarian environmentalism since 2012. As far as studies on China's CWG are concerned, more research is needed to critically examine China's authoritarian environmentalism under which various forms of CWG play out.

\subsection{Fieldwork and Data}

One of China's major environmental crises is water pollution and water scarcity related to coal mining. Coal mining has huge impacts on local water resources, threatening the access to water sources of those communities adjacent to coal mining sites [29]. Water pollution from mine waste rock and tailings may require management for decades, if not centuries, after the closure of coal mines. Despite the evident linkage between coal mining and the water scarcity crisis, more than 1100 new coal plant projects are inaugurated annually in today's world. Furthermore, many of the newly inaugurated coal plant projects are located in water-stressed regions-regions already strained by limited water supply for sanitation, health and livelihood [30].

Coal mining particularly dampens China's water scarcity challenges-independent estimates suggest that between 800 and 3000 gallons of water are required to produce a ton of coal in China [31]. China's largest coal basin stretches across five provinces in the North and water scarcity in this region has already hampered coal production, especially for smaller, less-efficient mines. Moreover, coal mining causes serious groundwater losses, bringing the contradiction between water shortages and socio-economic development to the fore. For example, a coal chemical project in the arid Inner Mongolia region extracted so much underground water in the eight years of its existence that it caused the local water table to drop by up to $100 \mathrm{~m}$ and the water area of one local lake shrank by $62 \%$ [32]. These drastic ecological impacts forced thousands of local residents to become "ecological migrants". This is just the tip of the iceberg - by 2015, China's sixteen mega coal power bases were estimated to consume 10 billion cubic meters of water annually, almost one sixth of the Yellow River's annual flow [33].

As the largest coal producing province in China, Shanxi has contributed $25 \%$ of China's annual coal output in recent years. Such an outstanding "achievement" took a tremendous toll on the local environment. According to a recent survey, coal mining has resulted in water shortage crises in 5266 villages of Shanxi, where nearly 3000 villages 
(with a total population of two million) are located in the goaf areas [34]. Apart from water resource shortages, those goaf areas are also prone to other environmental hazards such as land subsidence, cracks in houses and even building collapse. Geological, hydrological, vegetational and environmental changes in these goaf areas pose serious threats to the normal life of local communities [35].

The first and second authors of this paper conducted intensive fieldwork in 11 villages of H city, Shanxi Province, between 2019 and 2021. All 11 villages have faced water shortage problems since the late 1950s when large-scale coal mining spearheaded by state-owned mining companies took place. Villagers in these villages previously had access to natural spring water, but it dried up after the commencement of large-scale coal mining. H City is an industrialized region and local villagers have an above-average living standard in Shanxi, with an average annual disposable income of more than 16,000 RMB per capita in 2020. Unlike many villagers in the remote rural area who lack access to safe water due to geographic and economic reasons, the 11 villages in $\mathrm{H}$ City have been confronted with unstable drinking water supply caused by coal mining, a situation that in some cases has even triggered mass protests by local villagers. The most recent protest took place in the first half of 2020 when residents of Song village gathered in the front gate of the city government to protest the months-long suspension of drinking water (Interview H11, Song Village, 10 August 2020). Figure 2 demonstrates the geographic locations of H City, the three state-owned mining companies and the 11 villages in our case study.

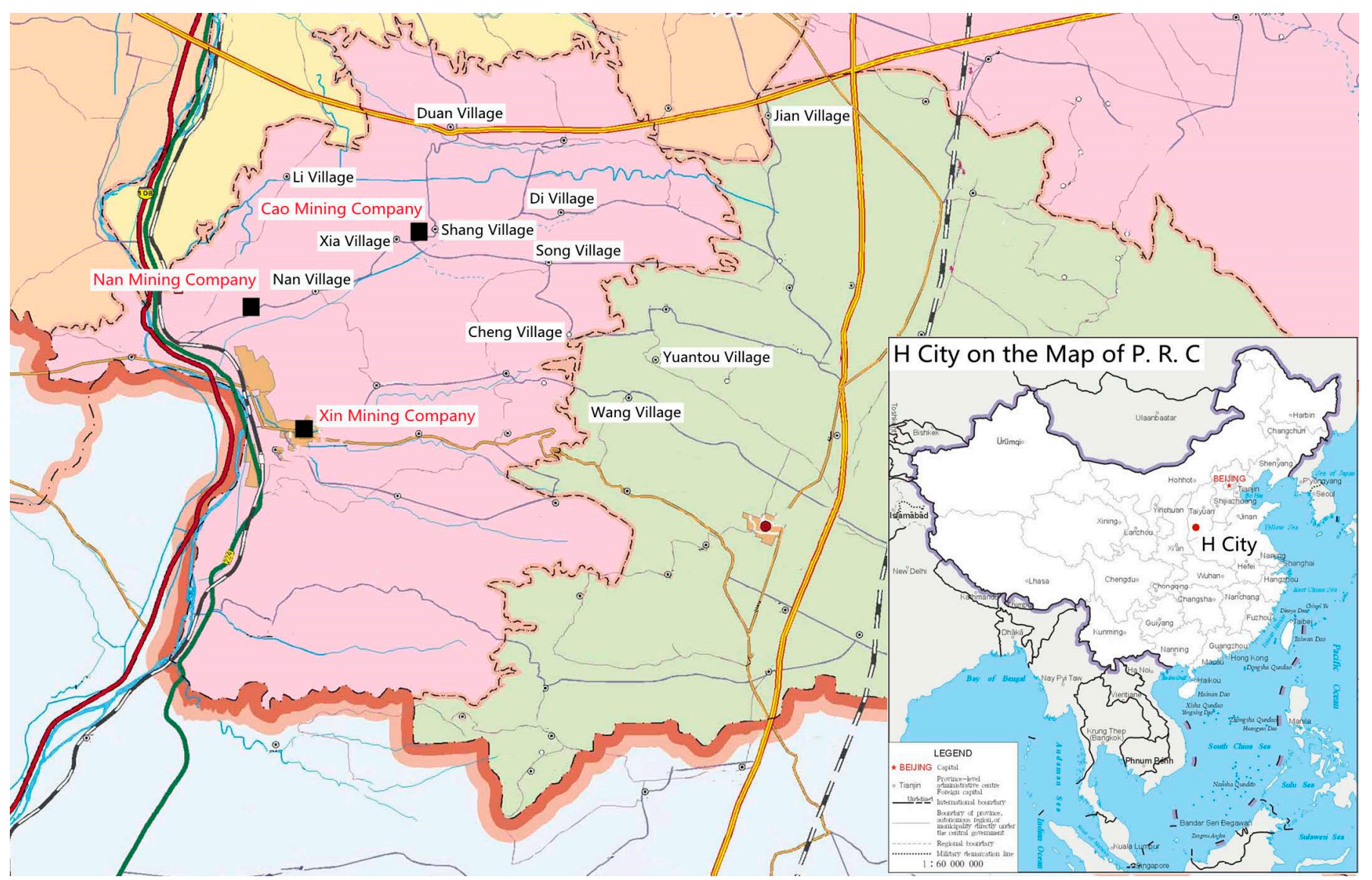

Figure 2. Geographic locations of H City, the three state-owned mining companies and the 11 villages. Source: adapted by the authors.

This study is based on participation observation and in-depth interview. The first author of this article has better access to the fieldwork in those villages because one of them is his hometown. The primary data and materials for this study consist of interviews, 
village chronicles and CME documents and archives collected from fieldwork. Secondary sources were collected from various websites, newspapers, magazines, journals and other public texts. Interviews were semi-structured in design. Interview questions concentrate both on the history and current situation of drinking water supply in villages. We also realized some difficulties during the fieldwork, including dwindling village population due to rapid urbanization, ignorance of most villagers on the details of water governance in their villages and the aversion of some villagers, government officials and CME employees to talk to researchers, which precluded the possibility to select interviewees in a random way. The interview quality is much better with those key informants who know more about the details and history of cooperative water governance in the villages. In the end, researchers interviewed 60 interviewees including officials from both county-level government departments and township governments, villagers, village cadres and managers of CMEs for this study. Our fieldwork finds that water supply in the 11 villages shares the following features:

First, drinking water supply has long been unstable. Most of the 11 villages can only supply drinking water for their villagers once every two days at best. The supply of drinking water can be especially problematic by issues such as pump breakdown, pipeline damage, decreasing underground water level, water quality deterioration, frozen pipeline in the winter season and the inability of villages to pay pumping water-incurred electricity expenses (Interview H1, Song Village, 10 April 2019; Interview H7, Wang Village, 5 August 2020; Interview H8, Cheng Village, 6 August 2020). Under such circumstances, drinking water supply in these villages can be suspended for months, if not years, forcing local villagers to fetch water from afar during the water supply crunch (Interview H6, Yuantou Village, 5 August 2020).

Second, villagers are concerned about the drinking water quality. Water quality in these villages cannot be guaranteed due to the lack of testing and lack of filtration and disinfection facilities. In most cases, underground water is directly pumped to the households, without going through any disinfection measures. What is more, the quality of underground water is prone to be affected by coal mining activities. In several cases, water quality was so unbearable that villagers vehemently demanded the Coal Mining Enterprises (CMEs) dig new wells for them, a demand that invariably triggered conflicts and back-and-forth negotiations between the villages and CMEs.

Third, although various Chinese laws and regulations require local governments to supply drinking water for their rural populations, the local city and township governments are reluctant to directly get involved in safe water supply projects in these villages. Instead, local governments preferred a CWG model as the solution, in which CMEs and affected villages are expected to negotiate a solution to the problem of drinking water supply in these villages. All 11 villages in our case study have signed drinking water supply agreements with three local state-owned CMEs. These agreements generally specify the obligations of the CMEs to restore and maintain a stable water supply for the affected villages, including, but not limited to, digging wells, installing pipelines, maintaining the water supply infrastructure and covering electricity costs incurred by water pumping etc. (Interview H1, Song Village, 10 April 2019). From the perspective of the local government, the natural water sources formerly available to these villages were destroyed by CME activity; therefore, the CMEs are responsible for making amends (Interview H11, Song Village, 10 August 2020). The legal basis for this can be found in the Law on Water of the P.R.C, first promulgated in 1988, which requires mining entities to compensate for the losses from water table drop, water source dry-up or the occurrence of sinkholes caused by their mining activities (Article 31) [36].

Fourth, villagers do not have to pay for the drinking water they use. In the 11 villages, drinking water supply has long been free to all villagers. As mentioned above, villagers in the 11 villages used to have free access to natural water sources, which only dried up after the arrival of the CMEs. From the villagers' perspective, the CMEs are obliged to supply free drinking water for them because the CMEs destroyed the water resources that 
previously provided free clean drinking water. Villagers claimed that they have the right to continue to enjoy free drinking water supply as their ancestors did (Interview H3, Duan Village, 5 August 2019).

\section{From Fragmented Authoritarianism to Authoritarian Environmentalism? Mapping out the Political Context of CWG in China's Water Politics}

\section{1. "Fragmented Authoritarianism" Model}

China has a long tradition of controlling water for political purposes. Literature on Chinese hydropolitics has long held that the empire's ability to regulate China's rivers was a crucial part of their political legitimacy [37]. To that end, over its long history the Chinese government has built a number of high-level bureaucratic institutions to maintain its centralized control of water and power [38]. More recently, the Three Gorges Dam Project and the South-North Water Transfer Project (SNWTP) provide two large-scale examples of how the Chinese state continues to assert its authority through controlling and engineering water [39].

Since the 2000s, a substantial body of literature has applied the "Fragmented Authoritarianism" model (FA model) in Chinese politics to explore China's local water politics [40]. The classic FA model describes the complex, multilevel bureaucratic arrangement by which policy is made at the central level while its implementation is reshaped by the interests of those who are expected to implement it. Through the lens of the FA model, the big paradox in China's water politics emerges: on the one hand, the central state needs to maintain its legitimacy through controlling water in a centralized authoritarian manner; on the other hand, however, its water management system at the local level is highly fragmented and decentralized in nature. Consequently, water policies of the various agencies often conflict with one another, and a deficit of cooperation and coordination across levels of government, bureaucratic agencies, public and private sectors, regions and watershed obviously presents on-going challenges [41].

Some studies reveal that the FA model can also explain interactions among various stakeholders in general and their blame generating and blame shifting games in particular, which generally lead to policy implementation gaps in China's decentralized environmental politics [42]. Some researchers even claim that China's policy-makers may have intentionally chosen this fragmented system because it obscures who should get blamed when water policies fail and who should receive credit when they succeed. Despite its ineffectiveness in cleaning up pollution, this decentralized system of environmental governance may have prevented the central government from being blamed for policy failures, thus reducing the risk of erosion of the central government's legitimacy [42].

Nevertheless, the macro-political context under which water politics play out in China has experienced a sharp turn from de facto decentralization to re-centralization since 2012 [14]. In recent years, the Party has relentlessly re-centralized its power through measures such as sending Central Environmental Protection Inspection Teams to local areas and implementing anti-corruption and responsibility attribution campaigns targeting local environmental officials [43-46]. In 2017, the announcement that "the Party exercises overall leadership over all areas of endeavor in every part of the country" was included in the revised Constitution of the CPC, demonstrating the Party's determination for further centralization.

Under such circumstances, "selective implementation" and huge gaps between environmental policy and implementation, which were lamentable hallmarks of the Hu-Wen era, have given way to "over-implementation" or "enthusiastic policy implementation" in recent years [47]. Officials at each level face ever-increasing responsibility attribution pressures thanks to a number of supervision, inspection and investigation campaigns in recent years. As a result, a large number of officials have been disciplined for problems involving air and water pollution and other environmental problems [48]. For example, due to the Environment Protection Inspection Campaign initiated by the Central Government, 221 officials were punished in Hubei Province alone in 2018 [49]. Several recent 
studies have shown that one of the unintended policy consequences of this "iron hand" recentralization is the "blunt force" style (yidao qie) environmental policy implementation at the local levels where the local variations, realities and autonomy are basically ignored [50].

\subsection{The Rise of the Authoritarian Environmentalism Model}

Recent literature on Chinese environmental politics argues that in the context of the more centralized power structure since 2012, the FA model is increasingly giving way to the Authoritarian Environmentalism model [51] (see Table 1). New terms such as "State-led Environmentalism", "Coercive Environmentalism", "Authoritarian Environmentalism" and "Eco-Authoritarianism" have emerged to characterize the re-centralization drive in Chinese environmental politics [15,52]. The Authoritarian Environmentalism model illustrates not only how the Chinese government uses top-down means for the end of better environmental governance but also how state-led environmentalism often serves non-environmental ends by strengthening the power of the Chinese state [15]. For example, $\mathrm{Li}$ and Shapiro identify pollution crackdowns, centrally administered campaign-style inspections, targetsetting, behavior modification, forcible relocations, big data monitoring, manipulating global trade and geoengineering as the primary governmental instruments employed in the name of environment for the end of strengthening the state's authoritarian resilience in China [15].

Table 1. "Fragmented Authoritarianism" vs. "Authoritarian Environmentalism" Model in China's Environmental Politics and Governance.

\begin{tabular}{|c|c|c|}
\hline & Fragmented Authoritarianism & Authoritarian Environmentalism \\
\hline Policy Making & $\begin{array}{l}\text { - } \quad \text { Centralized } \\
\text { Policy and bureaucratic conflicts } \\
\text { among agencies }\end{array}$ & $\begin{array}{l}\text { - } \quad \text { Re-centralized } \\
\text { Policy and bureaucratic conflicts are } \\
\text { covered by strong Central leadership }\end{array}$ \\
\hline $\begin{array}{l}\text { Policy } \\
\text { Implementation }\end{array}$ & $\begin{array}{ll}- & \text { Decentralized } \\
\text { - } & \text { Implementation gap }\end{array}$ & $\begin{array}{l}\text { - Political campaign "blunt force" style } \\
\text { - } \quad \text { "Enthusiastic policy implementation" }\end{array}$ \\
\hline Policy Evaluation & $\begin{array}{ll}\text { - } & \text { Incentive } \\
\text { - } & \text { Local official's career mobility } \\
\text { - } & \text { Credit claiming }\end{array}$ & $\begin{array}{l}\text { - } \quad \text { Party discipline } \\
\text { - } \quad \text { Hold local officials accountable } \\
\text { - } \quad \text { Blame avoidance }\end{array}$ \\
\hline Policy Feedback & $\begin{array}{l}\text { - } \quad \text { Public participation } \\
\text { - } \quad \text { Media supervision }\end{array}$ & $\begin{array}{ll}\text { - } & \text { Central inspection } \\
\text { - } & \text { Mass mobilization }\end{array}$ \\
\hline Policy Rhetoric & $\begin{array}{l}\text { - Hu Jintao's "Scientific Outlook on } \\
\text { Development" and "Harmonious } \\
\text { Society Construction" }\end{array}$ & $\begin{array}{l}\text { - Xi Jinping's "Ecological Civilization } \\
\text { Thoughts" and "Two Mountains Theory" }\end{array}$ \\
\hline
\end{tabular}

Comparative environmental politics studies have a long tradition of debating the correlation between regime type and the performance of environmental governance $[53,54]$. The majority of scholarship, theoretically as well as empirically, claims that the democratic political system has a better performance on environmental governance than authoritarian systems due to its high information flow and meaningful public participation in the policymaking process [55]. Critics of this position argue that politicians in liberal democratic systems need economic development and high employment rates to gain popular support, hence they tend to focus more on short-term developmental goals at the cost of long-term environmental goals [56]. Meanwhile, some research shows that public participation in the environmental policy-making process may have certain negative consequences because 
ordinary people are not able to deal with the complex information and lack the technical know-how necessary for successful environmental governance [57].

The concept of Authoritarian Environmentalism emerged as an alternative mode to approaching environmental challenges that democratic systems are not sufficiently capable of addressing. Advocates of the Authoritarian Environmentalism model claim that authoritarianism is probably more effective than democracies in addressing both domestic and global environmental crises. Some even contend that authoritarian regimes are indispensable for tackling environmental crises. The Authoritarian Environmentalism model argues that: (1) Individual freedom of citizens in general and behaviors with negative environmental impact in particular should be restricted; (2) The scope and depth of public participation in environment-related decision making should be restricted and eco-elites and environment experts should play the dominant role in decision making; (3) Power should be centralized at the central level and the roles of local areas, enterprises and social organizations in environmental governance should be limited; (4) Government regulation of the environment is necessary and reliance on economic incentives or the market mechanism is insufficient [16]. For example, Beeson argues that "environmental authoritarianism", in which the central state dominates individual liberty and any behavior damaging to the environment is forbidden, may prove to be essential for responding to the continuing environmental challenges in East Asia and Southeast Asia where the authoritarian tradition is deeply embedded in local cultural, social and political systems [16].

However, the dynamics of China's Authoritarian Environmentalism, its intended and unintended outcomes as well as its implications to environmental governance both at home and abroad are still open questions that require further exploration. For example, in looking at China's climate change policy, Gilley finds that Authoritarian Environmentalism is more effective in producing policy than in producing results [54]. Put differently, the advantage of the authoritarian regime lies in its ability to make quick and centralized policies to deal with the environmental issues, but policy alone does not lead to results due to the implementation gap and participation deficit at the local levels in authoritarian countries [58]. Eaton and Kostka also doubt the effectiveness of China's "Environmental Authoritarianism" model. They find that the high turnover rate among leading local cadres, resulting from the CPC's demands that local cadres faithfully implement policies decreed by central authorities, may hinder the environmental policy performance since officials with shorter time horizons tend to opt for quick and perfunctory implementation approaches, leaving complicated and intractable environmental problems to their successors [59].

Enlightened by the above studies, we will examine how the CWG model regarding Shanxi coal mining villages' safe water supply project works under the political context of authoritarian environmentalism in the following two sections. In doing so, we can extend the study of the authoritarian environmentalism model from its more urban-centric context to the remote rural parts of China where central governmental control and authority are generally assumed to be weaker.

\section{Policy Outputs: The Feature of Authoritarian Environmentalism in Safe Water Supply Projects in Rural China}

Gilley's study of China's climate change policy finds that "authoritarian environmentalism" is more effective in producing policy output than outcomes [54]. What are the policy outputs regarding safe water supply in rural China? Our documentary analysis of laws, official documents, leadership speeches and media reports find that the central government and top Chinese leaders have attached great importance to the SWSP in rural areas. Policy instruments under authoritarian environmentalism like centrally administered campaignstyle inspections and target setting have been widely employed in producing policy output related to SWSP in rural areas. The central authorities' policies and rhetoric regarding safe water supply in the rural areas are congruent with the authoritarian environmentalism model in the following three aspects: government leaders' public pronouncements; central government policies to be implemented locally; and local accountability. 


\subsection{Studying Top Leaders' Thoughts and Speeches on Water Governance Is the Guideline for SWSP}

Our documentary and media discourse analysis finds that the Chinese leadership attached unprecedented importance to water governance and drinking water supply in rural areas starting with the 18th Party Congress in 2012. President Xi's "Thoughts on Ecological Civilization" in general and his "strategic thoughts on water governance and improvement of water-related work" in particular were identified as guidelines for water governance. Official government documents summarized Xi's ideas on water governance as "prioritizing water conservation, achieving water balance across the country, realizing systemic governance and enabling the government and the market to play their respective roles". According to these official documents, "in-depth study of Secretary General Xi's important strategic thoughts on water governance and improvement of water-related work" is the crux of realizing good water governance in China [60]. In one article, the Minister of the Ministry of Water Resources confidently argues that "Secretary General Xi's important strategic thoughts on water governance and improvement of water-related work are bound to muster a powerful force within the Party and Chinese society to manage water and improve water-related work, providing a more secure water supply on our way to realizing the Chinese dream of the great rejuvenation of the Chinese nation [61]".

Apart from this paternalistic approach to rural drinking water supply issues in their speeches. Top Chinese leaders also employed nationalist rhetoric emphasizing that water governance is "vital to the survival, development and unification of the Chinese nation [62]". As President Xi's speech stressed, "water security is an important issue that affects the governance of our country. Our party must raise the awareness of the water crisis and water insecurity. We must pay more attention to issues related to water security from the strategic perspective of building a moderately prosperous society in all respects and achieving sustainable development for the Chinese nation [63]". During a field trip to rural areas of Anhui Province in 2020, he reiterated that "the Chinese nation has been chastened by our fight against natural disasters in history. We have gotten invaluable experiences from such a fight, which should be continued in the future [64]". His remarks are reminiscent of the water politics philosophy of the Mao era which encouraged people to fight a war against nature [65].

\subsection{Central Government Commitment to Safe Drinking Water as A Public Good in Rural Areas While Shifting Responsibility to Local Governments}

The Central Government has unequivocally made its commitment to supplying safe drinking water for the rural areas. For example, the Report of Government Work in 2014 announced that "China will address the unsafe drinking water problem for 60 million rural residents in 2014 and all of China's rural residents should have access to safe drinking water in 2016 [66]". Numerous official news outlets published the speech of Premier Li Keqiang, during his inspection visit to the Department of Rural Water Resources of the Ministry of Water Resources. In his speech, Premier Li pledged that it is the government's obligation to supply safe drinking water to all of China's rural residents and provide them with the basic infrastructure for drinking water supply. He urged that governments at various levels must work harder to meet their commitments to the people since all the difficult tasks had to be accomplished in 2015 [67].

However, Li's promises did not materialize until 2021. The No. 1 Document issued by the CPC Central Committee in 2019 acknowledged that "more effort should be made to improve the supply of safe drinking water, protect drinking water sources and resolve issues like unstable drinking water supply and supply of unsafe drinking water in rural areas [68]". In 2020, the CPC Central Committee and the State Council issued "Suggestions on Prioritizing the Development of Agriculture and Villages and Improving Our Work Related to Agriculture, Rural Areas and Farmers," in which the Chinese government vowed to implement the SWSP, strengthen the protection of drinking water sources in rural areas 
and address problems like drinking water supply shortages and the supply of unsafe drinking water [69].

The central government made it clear that local governments should take primary responsibility for providing safe water to the rural residents under their jurisdiction. The central government has the decision-making power for the division of labor among different levels of government and framed its role as the coordinator which can provide supplementary financial resources. The provincial government is required to take overall responsibility and lower-level governments are responsible for policy implementation of SWSP. According to law and central government policies, ensuring a stable supply of safe drinking water in rural areas is one of the basic public services of the various levels of local government. For example, "Regulation on the Management of Building Safe Drinking Water Projects in Rural Areas," issued jointly by the National Development and Reform Commission and Ministry of Water Resources in 2013 unequivocally states that "local governments should take the responsibility to ensure the supply of safe drinking water in rural areas and local governors should take the primary responsibility [70]".

\subsection{Holding Local Officials Accountable: Target-Setting and Campaign-Style Central Inspection}

In recent Five-Year Plans, the central government established SWSP as one important task and target in the strategy of "pushing forward all-round rural vitalization." The policy document stated that by 2020, government should further increase the collective water supply and running water accessibility to villages and should provide a stable supply of drinking water that meets quality standards with the goal of completely resolving issues related to drinking water supply and safety for China's poor population. The central government believed that more effort should be made to scrutinize the performance of local officials to make sure they "faithfully" meet Village Drinking Water Safety Standards and targets. According to a policy document, local governmental officials at the city and county levels were to be evaluated for their performance in ensuring drinking water supply to villages, improving water purification facilities and checking water quality regularly.

The central government continued to warn local officials that the performance evaluations would be strictly carried out and commanded the Provincial Bureau of Water Resources to supervise the implementation of the targets. According to the policy, township governments should bear the responsibility for managing small-scale SWSP, while Party village branches and village committees should ensure the management and maintenance of safe water supply facilities. The central government's policy document warned that local officials would be punished if they failed to provide safe water to villages or negligent of serious water quality problems [71]. The central government sent inspection teams to investigate the implementation of SWSP in rural areas. According to the official reports in 2020, more than 23,000 rural households in over 7000 villages in more than 500 counties across the country were secretly interviewed. After the completion of the covert inspection, the Ministry of Water Resources compiled a list of problems exposed in each province and closely monitored the correction of these problems by local governments. Under pressure from the central government, the provincial governments of Jilin, Sichuan and Guizhou intensified their undercover inspections to ensure local governments in their provinces took their responsibilities. Provincial governments like Anhui, Fujian and Jiangxi also investigated the outstanding problems regarding the drinking water supply for the poor rural population. Provincial governments of Guangdong and Shandong entrusted third-party entities to carry out relevant inspection and performance evaluation work [72].

The Shanxi Provincial Government initiated a "100-Day Campaign for Inspecting Water Governance," which covered issues related to village drinking water safety in all cities and counties in Shanxi province. A variety of mechanisms were put in place to ensure that the exposed problems were addressed. The official document stated that, "all the problems collected through various channels have been carefully recorded by relevant government agencies. In particular, responsible personnel were tasked to supervise the resolution of problems collected through the 12,314 hotline sponsored by the Ministry of 
Water Resources. Mechanisms like re-inspection, performance monitoring and weekly reporting on the resolution of problems collected through the 12,314 hotline were also employed [72]". However, our fieldwork did not find any instances of local officials being held accountable for problems in the SWSP in villages.

\section{Policy Outcomes: CWG as the Local Governments' Implementation and Blame Avoidance Strategy}

In the coal mining villages, whether and to what extent the central government's policies on safe water supply projects have resulted in measurable outcomes is contingent on how effectively CWG works in reality. Some researchers argue that local governments' "blunt force" enforcement is an unintended outcome of the central government's air and water pollution control policy under the political context of authoritarian environmentalism. The "coal to gas project" in Hebei, Shanxi and many other northern provinces are cases in point [50]. However, our fieldwork reveals that local governments' implementation strategies can be identified as a type of CWG mode when it comes to the safe water supply projects. Instead of using campaign-style implementation, local governments in H City prefer to encourage and facilitate CMEs and villages to negotiate drinking water supply agreements to address supply problems in the villages.

\subsection{Signing Drinking Water Supply Agreements}

The CWG approach cherishes such values as bargaining, negotiation and compromise. CWG advocates believe that collaboration is especially effective in resolving conflicts, improving relations among stakeholders, addressing multifaceted problems and correcting the deficiencies of the approaches that emphasize centralized government control or technical knowledge. In line with the CWG approach, these drinking water supply agreements epitomize the cooperation, deliberation and compromises between these villages and CMEs in their efforts to find solutions to the SWSP in these villages affected by coal mining activities of CMEs. The process of negotiating a drinking water supply agreement between these villages and CMEs can be described by three stages:

First, the affected village sends a formal complaint about the drinking water problem to CMEs. In response, CMEs send engineers to the village to verify that the problem is caused by mining activities of the enterprises. Second, once verified, the CME's Office for Village Affairs (OVA) summons village cadres for negotiations on making amends. Negotiations generally take several rounds before an agreement is reached. CMEs often hire law firms to facilitate negotiations with village cadres and ensure that the agreements are consistent with established laws, regulations and government policies. Third, after an agreement is reached, OVA, the Villagers' Committee of the village and the law firm will formally sign it prior to implementation. Such agreements generally specify the CMEs' obligations to restore and maintain stable water supply for the affected villages, including, but not limited to, digging wells, installing pipelines, maintaining the water supply infrastructure and covering electricity costs incurred by water pumping.

All 11 villages in our fieldwork have signed such agreements with CMEs, making these CMEs legally obligated to ensure a stable supply of drinking water for these affected villages. This alone, however, cannot guarantee the safe water supply in the villages since the enforcement is highly dependent on the stakeholders' ability to cooperate and manage conflict.

\subsection{Stakeholders and Their Cooperation and Conflicts}

5.2.1. Department of Water Resource (DWR) of the City Government

As stipulated by laws and local regulations, the DRW of H City government is responsible for building drinking water facilities for villages, including digging wells, installing pipelines and ensuring the safety of drinking water. In reality, the DRW did build drinking water supply facilities for some of H City's villages, but these villages have to cover the costs related to operation (e.g., personnel and electricity) and maintenance (e.g., pump 
repair) of these facilities. For those villages affected by coal mining activities (like the 11 villages under investigation here), the DWR generally leaves its responsibilities to CMEs who are expected to make amends since their mining activities are responsible for the water problems. The DWR levies fees on CMEs such as fees for soil and water loss and fees for water resource management, etc. As a result, it enjoys a strong position in its relations with CMEs (Interview H14, Nan Village, 30 September 2021). Pressured by DWR, the CMEs have to take the responsibility of drinking water supply for villages affected by their mining activities even though they may not view it as their sole responsibility. When conflicts regarding drinking water supply do emerge between the villages and CMEs, the DWR largely stays out of the fray since it is not legally obligated to mediate between them.

The city government evaluates the performance of the DWR in ensuring drinking water supply for villages through such indicators as the rate of collective water supply and tap water, the stability of the drinking water supply and water quality in rural areas. In practice, however, these indicators are not hard targets and no DWR official has ever been disciplined or held accountable for the poor performance on these indicators. In addition, the higher-level governments have no effective institutional mechanism for verifying the data on the villages' drinking water supply. As a result, the DWR might sometimes choose to manipulate the data on drinking water supply in villages in order to "perform well" on these indicators (Interview H14, Nan Village, 30 September 2021).

\subsubsection{The Township Government}

Our fieldwork finds township government is often very passive, if not negligent, in addressing drinking water supply shortages in these villages (Interview $\mathrm{H} 2$, downtown, $\mathrm{H}$ City, 1 August 2019). Although they generally play a facilitating role in negotiations about drinking water supply between CMEs and the villages, the township governments did not monitor the implementation of such agreements. In addition, the township governments opted out of disputes between CMEs and the villages regarding the implementation of drinking water agreements. Only when the conflicts threatened social stability would local township governments decide to intervene.

According to a retired township government official, almost all the villages under the jurisdiction of the township government he worked for were more or less affected by mining activities of CMEs and most of them had signed drinking water supply agreements with relevant CMEs (Interview H2, downtown, H City, 1 August 2019). Even local villagers tend to think that supply of drinking water falls within the responsibility of CMEs rather than the local township governments. For example, local villagers usually appeal to CMEs rather than the township governments in the event of drinking water supply shortages. From the perspective of local township governments, the agreements reached between villages and CMEs should have resolved the drinking water problem in these villages. The township governments even charged CMEs fees for their mediation efforts between CMEs and local villages but were not able to provide financial resources to help resolve such conflicts (Interview H2, downtown, H City, 1 August 2019; Interview H14, Nan Village, 30 September 2021).

\subsubsection{Coal Mining Enterprises}

CMEs play a mixed role in the safe water supply project for these villages affected by their mining activities. On the one hand, they are responsible for problems in the drinking water supply in these villages. On the other hand, however, by providing facilities and financial resources, they also play a major role in addressing the villages' drinking water supply problems. The three CMEs in our study are affiliates of the same mining conglomerate owned by the Provincial government and their leaders have much higher administrative rank than the DWR officials and township government officials, let alone village cadres. According to CME employer, however, their administrative ranks do not guarantee they would have more advantages in their disputes and negotiations with the villages. On the contrary, they complain that local governments and villages attempted 
to raise unreasonable demands and win more concessions from them since they, as stateowned enterprises, are expected to contribute more to the welfare of local communities. According to a local regulation, the city government levies a special tax on state-owned CMEs for potential environmental damages caused by their mining activities. By paying this special tax, CME officials insist that they have compensated for all the environmental damages caused by their mining activities, including the drinking water supply problem in surrounding villages. If they are still required to take the responsibility for addressing the drinking water supply problem in nearby affected villages, as they have long been forced to do in reality, they argue they are punished twice for the same wrong.

CMEs are expected by both the local governments and villages to shoulder a list of drinking water supply-related responsibilities like digging wells, building the pipelines, providing pumps and covering operation and maintenance costs, etc. With the expansion of their mining activities, their responsibilities to supply drinking water to villages became heavier since more villages were affected by their mining activities. Under such circumstances, CMEs have strong incentives to shirk their responsibilities regarding drinking water supply since it is financially stressful for them. However, CMEs cannot shirk their responsibilities at will. In reality, they are particularly exposed to the pressures from these affected villages. Since they are either physically located or have important facilities in these villages, they have to be very careful in handling their relations with these host villages.

In several cases, angry villagers have blocked streets linking CMEs to the outside or have destroyed their facilities in their protests against drinking water supply shortages. CMEs adapted to such violent scenarios by introducing two measures. First, they established the Office for Village Affairs (OVA), an organization specifically responsible for managing CMEs' relations with surrounding villages. The hope was that OVA would contain the escalation of conflicts with villagers and ensure the normal operation of CMEs. Second, CMEs tried to co-opt village cadres to avoid violent confrontations with the villagers. They introduced a rule in practice that authorized OVAs only to negotiate with village cadres but not with ordinary villagers. From the perspective of CMEs, direct engagement with individual villagers is too costly and time consuming and villagers are generally "untrustworthy" as they often renege on the settlements they have accepted from OVAs. As one OVA staff put it, "we must not handle our relations with surrounding villages person by person" (Interview H12, Cao Mining Company, 11 August 2020).

\subsubsection{Village Cadres}

As the gatekeepers between villagers and CMEs, village cadres have an important role to play in addressing drinking water shortages in their villages. In theory, village cadres are expected to defend villagers' interests in their negotiations with OVA staff. In practice, however, they are largely not accountable to villagers as not all village cadres are elected by villagers. In particular, the village party secretary, the most powerful figure in the village, is de facto appointed by the township Party Committee. As a result, village cadres enjoy considerable autonomy in their dealing with OVA staff. On the one hand, they are expected to get more resources from the DWR, the township government and the CMEs to ensure drinking water supply for their villages. On the other hand, however, they are prone to misappropriate these resources since they are generally not accountable to villagers, who lack effective mechanisms to rein in their corruption. In particular, village cadres tend to misuse the safe water supply project funding and other resources from CMEs for personal benefits since such off-budget resources are not overseen by any authority. To Gain More Resources from CMEs, however, village cadres have to foster close relations (guanxi) with OVA staff in the first place. For example, even though all the 11 villages have signed drinking water supply agreements with CMEs, village cadres still have to curry favor with OVA staff in order to secure the implementation of these agreements. When asked why drinking water supply had become a problem in their villages, some villagers responded with answers like "village cadres failed to reach out to CME staff", "relations between the village and CMEs became too loose due to the rapid turnover of village cadres" and "the 
problem may not be resolved 100\% if you have close relations with CME staff, but it will be 100\% unresolved without it (Interview H9, Nan Village, 8 August 2020; Interview H10, Li Village, 9 August 2020; Interview H13, Jian Village, 12 August 2020)." For example, one interviewee in Jian village told us that OVA staff turned their back on cadres of his village when the latter tried to negotiate a settlement on drinking water supply for his village (Interview H13, Jian Village, 12 August 2020). Another interviewee in Nan village, who used to be the deputy chief of the village, joked that "village cadres are not even allowed to enter the OVA office if they don't have close relations with OVA staff (Interview H9, Nan Village, 8 August 2020)."

\subsubsection{Villagers}

Among the five stakeholders in the CWG of SWSP, villagers are in a systemically inferior position, with neither effective mechanism for holding village cadres accountable nor easy access to the CMEs and higher-level government. It is no wonder that villagers became the primary victims in the drinking water supply shortages caused by misappropriation of funds by erratic village cadres, indifference from higher-level governments officials and the avoidance attitude of OVA staff. As mentioned above, the CMEs introduced a rule in practice that authorized OVA only to negotiate with village cadres but not with ordinary villagers, a measure that mostly closed the communication channel between villagers and CME representatives.

Having said that, villagers in the 11 villages are not completely powerless. They can resort to weapons of the weak, such as mass protests, blocking the main road and petitioning higher-level governments, even though doing so is always risky and costly for them. Should the drinking water supply shortage become so serious that it is completely unbearable for the villagers, mass protest is often the measure of last resort. As our respondents admit, the purpose of mass protest is to pressure CMEs to negotiate with villagers to resolve the drinking water supply problems (Interview H3, Duan Village, 5 August 2019; Interview H4, Wang Village, 6 August 2019; Interview H5, Di Village, 6 August 2019). For both the CMEs and village cadres, the risk of mass protests by villagers is a powerful constraint on the extent to which they can ignore their drinking water supply commitment or misuse the resources for addressing the drinking water supply in villages. For example, in April 2020, villagers of Song village gathered at the front gate of the city government to protest the months' suspension of their water supply. The city government responded by replacing the Party Secretary of the village with a new appointee who later managed to restore water supply to the village.

For villages that host important CME facilities, the threat of mass protests and disruptive behaviors from villagers is real such that CMEs were occasionally forced to make further concessions to villagers. For example, CMEs provided not only free drinking water supply but also free electricity to Nan village, Shang village, Xia village and Di village for many years. Ironically, free drinking water and free electricity supply gave rise to rampant waste of resources in these villages, imposing a heavy financial drain on the CMEs which were unsustainable in the long run. Consequently, CMEs were even more loath to implement the drinking water supply agreements with the villages.

\subsection{Transparency, Trust and Collusion in CWG}

Many researchers demonstrate that transparency and trust-building are essential for successful cooperation among stakeholders in CWG. Our fieldwork shows that the most difficult part of making CWG work in the villages was not reaching drinking water supply agreements among stakeholders but the implementation of the agreements. Lack of transparency in particular hampers the implementation of drinking water supply agreements. Few villagers we interviewed have the access to the information about the concrete content of drinking water supply agreements their village cadres signed with CMEs on their behalf. In several villages, when villagers asked cadres to disclose the drinking water supply agreements, they were told that the original agreements had been "lost" long ago. As 
the gatekeepers between the villages and CMEs, village cadres have strong incentives to withhold information about their dealings with OVA staff both because of the secretive nature of such dealings (fostering guanxi) and their intention to misappropriate the resources from such dealings. OVA staff are also averse to disclosing information on drinking water supply agreements to villagers. As mentioned above, OVA staff were instructed to only negotiate with village cadres but not with ordinary villagers, a measure which largely deprived ordinary villagers of access to information on drinking water supply agreements. Absence of both the township government and the DWR in monitoring the implementation of drinking water supply agreements further aggravates the information deficit faced by ordinary villagers (see Figure 3).

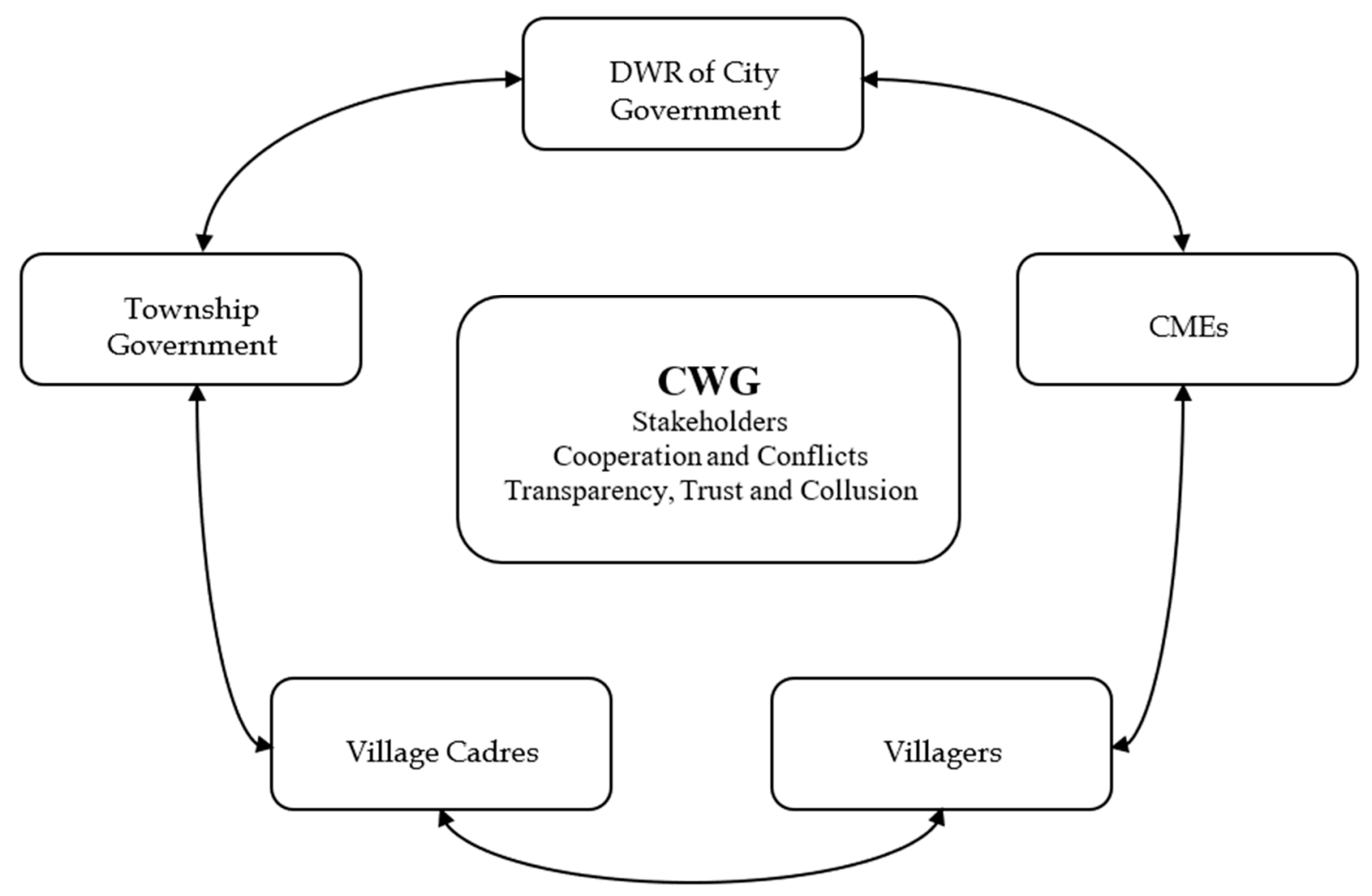

Figure 3. Stakeholders of CWG in village's SWSF.

Transparency deficit and information asymmetry between village cadres and villagers provide a hot bed for corruption, further reducing villagers' trust of village cadres. One villager complained that corruption by village cadres is an open secret in the village, even though few have been disciplined so far (Interview H8, Cheng Village, 6 August 2020; Interview H11, Song Village, 10 August 2020). As mentioned above, implementation of drinking water supply agreements depends on whether village cadres can foster close relations with OVA staff. Such a reality tends to compel village cadres to attribute the implementation of drinking water supply agreements and the resources for water supply in the village to their personal efforts, further strengthening their incentives for corruption. Both village cadres and OVA staff can benefit from such collusive relations: close relations between village cadres and OVA staff can go so far that in several cases they collude with each other. For village cadres, such collusion may be necessary to persuade CMEs to implement the drinking water supply agreements, providing them the much-needed resources that can be used both for collective and personal purposes. For OVA staff, collusion with village cadres can avoid possible conflicts with villagers and thus ensure the normal operation of CMEs on the one hand and create opportunities for personal enrichment on the other (e.g., bribery from village cadres). 
Trust deficit is also an acute problem between villagers and the CMEs. From the perspective of CMEs, villagers are "untrustworthy" because they tend to renege on the settlements they have accepted and want to gain more concessions from CMEs. This partly explains why CMEs introduced the "no negotiation with villagers" rule. For their part, villagers are also suspicious of CMEs for their secretive dealings with village cadres at the expense of ordinary villagers, a suspicion that is justified by the mysteries surrounding the drinking water supply agreements and exclusion of villagers from the negotiation process.

In theory, villagers can report the unaccountable village cadres or vote the Village Chief and the Deputy Village Chief out of office in the next election. In practice, such options are rarely pursued both due to the clan and kinship linkages between village cadres and some villagers and the fragmentation and lack of trust among villagers themselves. For example, although all the villagers in Song village suffered from the months-long suspension of drinking water in April, 2020, only some took part in the protest at the front gate of the city government. Villagers had strong incentives for free-riding since the restoration of drinking water supply is a public good with positive externalities for everyone living in the village.

\section{Conclusions}

The CWG approach emerged in the western political systems in response to the failures of government's command-and-control approach in managing water pollution and water scarcity. The successful implementation of CWG relies upon the existence of trust, participation, transparency, accountability and legitimacy which are often absent in some non-western systems. China is a country confronted by serious water pollution and shortage problems. In recent years, many scholars and practitioners have increasingly turned to the CWG model for solutions to water crisis management in China. However, the dynamics and performance of China's government-led CWG model is fundamentally embedded into the political context of China's environmental authoritarianism.

CWG development in China raised a theoretical puzzle, i.e., how can the bottom-up CWG model coexist with the top-down authoritarian environmentalism in China's water politics? To better understand this puzzle, this article explores the CWG's intertwinement with authoritarian environmentalism in SWSP in coal mining villages in Shanxi province of North China. Drawing on extensive fieldwork conducted between 2019 and 2021, this research suggests that the central government's pledge to provide safe water to every villager in rural China has not materialized so far. The dilemma in safe water supply in coal mining villages in Shanxi province showed that, one the one side, the central government attempted to demonstrate its great will and commitment to providing safe water to everyone in rural China through an approach of environmental authoritarianism; however, on the other side, local governments tend to select the CWG model as a practical implementation as well as a blame avoidance strategy. Our findings can be summarized by three important points:

First, the central government's ambitious promise to provide safe water to China's rural areas showed the features of the authoritarian environmentalism model in three ways: (1) It presents a paternalistic and nationalistic image for itself by demonstrating its political will to tackle drinking water supply problems in rural areas using lofty rhetoric and drafting ambitious action plans; (2) It shifts the implementation responsibility of ensuring drinking water supply in villages to local government officials; (3) It sets targets for evaluating the performance of local government officials in SWSP in villages and sends central inspection teams to hold local officials accountable when necessary.

Second, the local governments use the CWG model both as an implementation tool and a blame avoidance strategy to fulfill the central leadership's stated goal of providing safe water to villagers. Instead of resorting to the campaign-style implementation approach, local governments in our study preferred to encourage and facilitate various stakeholders to negotiate drinking water supply agreements in the villages. In the CWG process, the five stakeholders were the Department of Water Resource (DWR) of the City Government, 
the Township Government, Coal Mining Enterprises, village cadres and villagers. Neither the DWR nor the township government thinks safe water supply is their responsibility and has the incentive to avoid blame when facing conflicts and accountability pressures.

Third, the outcome of the water supply agreements greatly depends on cooperation and conflict management between CMEs, village cadre and villagers. Transparency and trust deficit among stakeholders in the implementation of water supply agreements are the main obstacles in the CWG's cooperation and conflict management process. On the one hand, the villagers generally know very little about the content of the drinking water supply agreements and are legitimately suspicious of collusion between the village cadres and CME staff and embezzlement of water supply funding by village cadres. On the other hand, CME staff tend to interpret villagers' protests against unstable drinking water supply as a "stage performance", whose real intention is to gain more material benefits from CMEs.

China became the world's second largest economic power in 2010. Since 2012, China has made tremendous progress in environmental and climate change governance which connects domestic environmental actions to global leadership on climate change and national revival. In the middle of the COVID-19 pandemic, the Chinese leadership announced an ambitious goal of becoming carbon neutral by 2060, committed to stop building coalburning power plants overseas and made pledges to inject $\$ 233$ million into a new fund to protect biodiversity in developing countries [73]. Despite the authority's political commitment and rhetoric, as of 2020, more than 60 million people in rural China are still plagued by shortages of safe and clean water supply. Our study in Shanxi's coal mining villages demonstrates how rural villagers' demand for safe water is caught in the middle in the game of the central state's authoritarian environmentalism and local officials' CWG approach. To better meet villagers' demand for safe drinking water supply, it is crucial to build trust and transparency among stakeholders so that both the performance and legitimacy of the CWG approach can be sustained.

Author Contributions: Conceptualization: J.Y., R.R. and R.L.; Fieldwork and Data: J.Y. and R.L.; Draft writing and editing: R.R. and J.Y. All authors have read and agreed to the published version of the manuscript.

Funding: The authors received no funding on this project.

Institutional Review Board Statement: Not applicable.

Informed Consent Statement: Informed consent was obtained from all subjects involved in the study.

Data Availability Statement: Not applicable.

Conflicts of Interest: The authors declare no conflict of interest.

\section{References}

1. Mekonnen, M.; Hoekstra, A. Four Billion People Facing Severe Water Scarcity. Sci. Adv. 2016, 2, e1500323. [CrossRef]

2. Ma, T.; Sun, S.; Fu, G.T.; Hall, J.W.; Ni, Y.; He, L.; Yi, J.W.; Zhao, N.; Du, Y.Y.; Pei, T.; et al. Pollution exacerbates China' s water scarcity and its regional inequality. Nat. Commun. 2020, 11, 650. [CrossRef] [PubMed]

3. The Ministry of Environment. 280 Million Chinese Have no Access to Safe Drinking Water. Available online: http:/ finance. people.com.cn/n/2014/0315/c70846-24642970.html (accessed on 6 October 2021). (In Chinese)

4. Katoria, D.; Sehgal, D.; Kumar, S. Environment impact assessment of coal mining. Int. J. Environ. Eng. Manag. $2013,4,246-247$.

5. Rojas, R.; Bennison, G.; Gálvez, V.; Claro, E.; Castelblanco, G. Advancing collaborative water governance: Unraveling stakeholders' relationships and influences in contentious river basins. Water 2020, 12, 3316. [CrossRef]

6. Ostrom, E.; Burger, J.; Field, C.B.; Norgaard, R.B.; Policansky, D. Revisiting the commons: Local lessons, global challenges. Science 1999, 284, 278-282. [CrossRef]

7. Harrington, C. The political ontology of collaborative water governance. Water Int. 2017, 3, 254-270. [CrossRef]

8. Holley, C. Crafting collaborative governance: Water resources, California's delta plan, and audited self-management in New Zealand. News Anal. 2015, 45, 10324.

9. Wilson, N.J.; Harris, L.M.; Nelson, J.; Shah, S.H. Re-theorizing politics in water governance. Water 2019, 11, 1470. [CrossRef]

10. Cisneros, P. What makes collaborative water governance partnerships resilient to policy change? A comparative study of two cases in Ecuador. Ecol. Soc. 2019, 1, 29. [CrossRef] 
11. Huang, C.; Chen, T.; Yi, H.T.; Xu, X.L.; Chen, S.Y.; Chen, W. Collaborative environmental governance, inter-agency cooperation and local water sustainability in China. Sustainability 2017, 9, 2305. [CrossRef]

12. Cain, B.E.; Gerber, E.R.; Hui, I. The challenge of externally generated collaborative governance: California' s attempt at regional water management. Am. Rev. Public Adm. 2020, 50, 428-437. [CrossRef]

13. Wang, Y.; Chen, X. River Chief System as a collaborative water governance approach in China. Int. J. Water Resour. Dev. 2020, 4, 610-630. [CrossRef]

14. Rooij, B.V.; Zhu, Q.Q.; Li, N.; Wang, Q.L. Centralizing trends and pollution law enforcement in China. China Q. 2017, 231, 583-606. [CrossRef]

15. Li, Y.; Shapiro, J. China Goes Green: Coercive Environmentalism for A Troubled Planet; John Wiley \& Sons: Hoboken, NJ, USA, 2020.

16. Beeson, M. The Coming of Environmental Authoritarianism. Environ. Politics 2010, 2, 276-294. [CrossRef]

17. Bentrup, G. Evaluation of a collaborative mode: A case study analysis of watershed planning in the Intermountain West. Environ. Manag. 2001, 27, 739-748. [CrossRef]

18. Ansell, C.; Gash, A. Collaborative governance in theory and practice. J. Public Adm. Res. Theory 2008, 4, 543-571. [CrossRef]

19. Cooper, T.L.; Bryer, T.A.; Meek, J.W. Citizen-centered collaborative public management. Public Adm. Rev. 2006, 66, 76-88. [CrossRef]

20. Ingram, H. Beyond Universal Remedies for Good Water Governance: A Political and Contextual Approach. Available online: https: / / www.researchgate.net/publication/238658113 (accessed on 7 July 2021).

21. Perreault, T. What kind of governance for what kind of equity? Towards a theorization of justice in water governance. Water Int. 2014, 2, 233-245. [CrossRef]

22. Guidone, A. Whose Knowledge, Whose Water, Whose Life? A Case Study of Water Governance and Mining in Sekhukhune, South Africa. Master's Thesis, Department of Environmental Studies, Queen's University Kingston, Kingston, ON, Canada, 2019.

23. Zhu, W. Exploring effectiveness of river chief system in water environment. Jiangsu Water Conserv. 2013, 10, 1-7. (In Chinese)

24. Huang, A. River chiefs system: Institutional form and innovation trends. Xuehai 2015, 4, 141-147. (In Chinese)

25. Huang, Q.; Xu, J. Rethinking environmental bureaucracies in River Chief System (RCS) in China: A critical literature study. Sustainability 2019, 11, 1608. [CrossRef]

26. Li, Y.; Tong, J.; Wang, L. Full implementation of the River Chief System in China: Outcome and weakness. Sustainability 2020, 11, 3754. [CrossRef]

27. Ouyang, J.; Zhang, K.Z.; Wen, B.; Lu, Y.P. Top-down and bottom-up approaches to environmental governance in China: Evidence from the River Chief System (RCS). Int. J. Environ. Res. Public Health 2020, 17, 7058. [CrossRef] [PubMed]

28. Wu, C.H.; Ju, M.S.; Wang, L.F.; Gu, X.Y.; Jiang, C.L. Public participation of the River Chief System in China: Current trends, problems, and perspectives. Water 2020, 12, 3496. [CrossRef]

29. Yu, X. Coal mining and environmental development in southwest China. Environ. Dev. 2017, 21, 77-86. [CrossRef]

30. Cheng, I.; Lammi, H. The Great Water Grab: How the Coal Industry is Deepening the Global Water Crisis. Available online: https:/ / storage.googleapis.com/planet4-bulgaria-stateless/2019/03/8f539a27-8f539a27-coal-water-aw-d28lores.pdf (accessed on 9 July 2021).

31. Moore, S. Issue Brief: Water Resource Issues, Policy and Politics in China; The Brookings Institute: Washington, DC, USA, 2013.

32. UNESCO. The United Nations World Water Development Report 2015: Water for a Sustainable World. Available online: https:/ / sustainabledevelopment.un.org/content/documents/1711Water\%20for\%20a\%20Sustainable\%20World.pdf (accessed on 8 August 2021).

33. Dong, S.N.; Xu, B.; Yin, S.X.; Han, Y.; Zhang, X.D.; Dai, Z.X. Water resources utilization and protection in the coal mining area of northern China. Sci. Rep. 2019, 9, 1214. [CrossRef] [PubMed]

34. Ciconsulting. Rural Environment: Various Pollution Makers and the Absence of an Environmental Monitoring System. Available online: http:/ / www.ocn.com.cn/chanjing/201604/hnvqx15094008.shtml (accessed on 4 October 2021). (In Chinese)

35. Li, Q.; Stoeckl, N.; King, D.; Policy, R.; Eggert, R.G. Using the life-satisfaction approach to quantify the complex inter-related impacts of coal mining on host communities: A case study in Shanxi, China. Resour. Policy 2019, 62, 305-316. [CrossRef]

36. The Law on Water of the People' s Repulic of China. Available online: http://www.gov.cn/ziliao/flfg/2005-08/31/content_2787 5.htm (accessed on 13 October 2021). (In Chinese)

37. Habich, S. Reasons to Dam: China's Hydropower Politics and Its Socio-Environmental Consequences; Palgrave Macmillan: New York, NY, USA, 2017; pp. 103-127.

38. Rogers, S.; Crow-Miller, B. The politics of water: A review of hydropolitical frameworks and their application in China. Wiley Interdiscip. Rev. Water 2017, 4, e1239. [CrossRef]

39. Moore, S. Hydropolitics and inter-jurisdictional relationships in China: The pursuit of localized preferences in a centralized system. China Q. 2014, 219, 760-780. [CrossRef]

40. Mertha, A. China's Water Warriors; Cornell University Press: Ithaca, NY, USA, 2011.

41. Wang, Y.; Liu, T.; Dang, H. Bridging critical institutionalism and fragmented authoritarianism in China: An analysis of centralized water policies and their local implementation in semi-arid irrigation districts. Regul. Gov. 2018, 4, 451-465. [CrossRef]

42. Ran, R. Understanding blame politics in China' s decentralized system of environmental governance: Actors, strategies and context. China Q. 2017, 231, 634-661. [CrossRef] 
43. Yang, X.; Yan, J. Top-level design, reform pressures, and local adaptations: An interpretation of the trajectory of reform since the 18th CPC Party Congress. J. Chin. Gov. 2018, 1, 25-48. [CrossRef]

44. Kostka, G.; Nahm, J. Central-local relations: Recentralization and environmental governance in China. China Q. 2017, 231, 567-582. [CrossRef]

45. Li, L. Politics of anticorruption in China: Paradigm change of the party' s disciplinary regime 2011-2017. J. Contemp. China 2019, 28, 47-63. [CrossRef]

46. Qiaoan, R.; Teets, J. Responsive authoritarianism in China-A review of responsiveness in Xi and Hu administrations. J. Chin. Political Sci. 2020, 1, 139-153. [CrossRef]

47. Deng, Y.H.; O' Brien, K.J.; Chen, J.J. Enthusiastic policy implementation and its aftermath: The sudden expansion and contraction of China's microfinance for women programme. China Q. 2018, 234, 506-526. [CrossRef]

48. Mei, C.; Pearson, M. Killing a chicken to scare the monkeys? Deterrence failure and local defiance in China. China J. 2014, 72, 75-97. [CrossRef]

49. HBTV. 221 Officials Were Held Accountable! Hubei Province Initiated an Unprecedented Responsibility Attribution Movement in the Field of Environment Protection. Available online: http://news.hbtv.com.cn/jszb/p/1256328.html (accessed on 13 October 2021). (In Chinese)

50. Kamp, D. Blunt force regulation and bureaucratic control: Understanding China's war on pollution. Governance 2021, 34, 191-209. [CrossRef]

51. Teng, F.; Wang, P. The evolution of climate governance in China: Drivers, features, and effectiveness. Environ. Politics 2021, 30, 141-161. [CrossRef]

52. Lo, K. Authoritarian environmentalism, just transition, and the tension between environmental protection and social justice in China's forestry reform. For. Policy Econ. 2021, 131, 102574. [CrossRef]

53. Winslow, M. Is democracy good for the environment? J. Environ. Plan. Manag. 2005, 5, 771-783. [CrossRef]

54. Gilley, B. Authoritarian environmentalism and China's response to climate change. Environ. Politics 2013, 2, 287-307. [CrossRef]

55. Barret, S.; Graddy, K. Freedom, growth and the environment. Environ. Dev. Econ. 2000, 5, 433-456. [CrossRef]

56. Shearman, D.; Smith, J. The Climate Change Challenge and the Failure of Democracy; Praeger: Westport, CT, USA, 2007.

57. Li, Q.; Reuveny, R. Democracy and environmental degradation. Int. Stud. Q. 2006, 50, 935-956. [CrossRef]

58. Kostka, G.; Mol, A. Implementation and participation in China' s local environmental politics: Challenges and innovations. $J$. Environ. Policy Plan. 2013, 1, 3-16. [CrossRef]

59. Eaton, S.; Kostka, G. Authoritarian environmentalism undermined? Local leaders' time horizons and environmental policy implementation in China. China Q. 2014, 218, 359-380. [CrossRef]

60. Xinhuanet. The Policy Orientation of Water Governance Reform and Development for the New Era. Available online: http: //www.xinhuanet.com/politics/2019-01/21/c_1210043433.htm?from=timeline (accessed on 9 October 2021). (In Chinese)

61. Chen, L. In-depth Study of Secretary General Xi's Important Strategic Thoughts on Water Governance. Available online: http:/ / cpc.people.com.cn/n/2014/0430/c164113-24961705.html (accessed on 15 October 2021). (In Chinese)

62. People' s Daily. Making Rush Mountains and Lucid Waters Benefit the People and Our Children: A Review of General Secretary Xi Jinping's Thoughts on Ecological Civilization. Available online: https://www.mee.gov.cn/ywdt/szyw/202106/t20210603_83 6135.shtml (accessed on 15 October 2021). (In Chinese)

63. Chen, L. The Guidance for Water Governance in the New Era: In-depth Study and Faithful Implementation of Secretary General Xi's Important Strategic Thoughts on Water Governance. Available online: http:/ / cpc.people.com.cn/n/2014/0801/c64102-253 84939.html (accessed on 15 October 2021). (In Chinese)

64. Xi, J.P. To Modernize the Ways in Our Responses to Natural Disasters. Available online: http://www.xinhuanet.com/2020-08/19 /c_1126385520.htm (accessed on 15 October 2021). (In Chinese)

65. Shapiro, J. Mao's War Against Nature: Politics and the Environment in Revolutionary China; Cambridge University Press: Cambridge, MA, USA, 2001.

66. Li, K.Q. To Ensure Safe Drinking Water Supply to Everyone. Available online: http://politics.people.com.cn/n/2014/1125/c100 1-26092200.html (accessed on 18 October 2021). (In Chinese)

67. Li, K.Q. To Ensure Safe Drinking Water Supply for Rural Areas and Bring Benefits to Millions of People. Available online: http:/ /cpc.people.com.cn/n/2014/1126/c64094-26093780.html (accessed on 16 October 2021). (In Chinese)

68. The CPC Central Committee and the State Council. Several Suggestions on Prioritizing the Development of Agriculture and the Rural Areas and Improving Our Work on Agriculture, the Rural Areas and Farmers. Available online: http://www.gov.cn/ zhengce/2019-02/19/content_5366917.htm (accessed on 16 October 2021). (In Chinese)

69. The CPC Central Committee and the State Council. Suggestions on Targeting Important Issues Regarding Agriculture, the Rural Areas and Farmers and Ensure the on-time Realization of the Objective of "Building A Moderately Prosperous Society in All Respects. Available online: http:/ / www.gov.cn/zhengce/2020-02/05/content_5474884.htm (accessed on 16 October 2021). (In Chinese)

70. National Development and Reform Commission and Ministry of Water Resources. Regulation on the Management of Building Safe Drinking Water Projects in Rural Areas. Available online: https://www.ndrc.gov.cn/fzggw/jgsj/njs/sjdt/201401/t2014011 7_1194718.html? code $=\&$ state $=123$ (accessed on 16 October 2021). (In Chinese) 
71. Ministry of Water Resources. Guiding Suggestions on Ensuring Water Supply for Rural Areas. Available online: http:/ /www.gov. cn/xinwen/2021-08/19/content_5632047.htm (accessed on 18 October 2021). (In Chinese)

72. Ministry of Water Resources. Report of the 2021 Work Meeting on Rural Water Resource and Hydro-power. Available online: http:/ / www.jsgg.com.cn/Index/Display.asp?NewsID=25831 (accessed on 18 October 2021). (In Chinese)

73. BBC. China Pledges to Stop Building New Coal Energy Plants Abroad. Available online: https://www.bbc.com/news/worldasia-china-58647481 (accessed on 25 October 2021). (In Chinese). 